\title{
Subsidies, Rent Seeking and Performance: Being Young, Small or Private in China*
}

\author{
Jun Du and Tomasz Mickiewicz. \\ Aston Business School, Aston University, Aston Triangle, Birmingham B4 7ET, UK
}

(in press in Journal of Business Venturing, 2015)

\begin{abstract}
Entrepreneurs in emerging market economies operate in weak institutional contexts, which can imply different types of government. In some countries (e.g. Russia), the government is predatory, and the main risk faced by (successful) entrepreneurs relates to expropriation. In other countries (like China) this kind of risk is lower; nevertheless the government is intrusive, and the rules of the game remain fluid. The implication of the latter for entrepreneurs is that they are more likely to spend time and resources on influence (rent seeking) activities rather than on productive activities. We illustrate this type of government by focusing on the distribution of subsidies in China. We present a simple formal model that explores not only the direct effects of rent seeking for a company but also externalities under a situation of policygenerated uncertainty in the distribution of subsidies. We explore how these effects differ for the entrepreneurial sector (young, private and small companies) compared with other sectors. We posit that while the performance of private companies is more affected than the performance of state firms, the impact of government-induced uncertainty on young and small companies is actually less pronounced. Our empirical analysis, based on a unique large dataset of 2.4 million observations on Chinese companies, takes advantage of the regional and sectoral heterogeneity of China for empirical tests.

Keywords: Rent Seeking; Subsidies; China; New firms

* We are grateful to Prof. Saul Estrin and Prof. Miriam van Praag for creating an excellent opportunity for us to develop the first idea of this paper at Entrepreneurship Week at the Green Templeton College, University of Oxford. We also benefited from opportunity to present this paper at a seminar at Stockholm School of Economics, RSA conference in Los Angeles, EACES conference in Budapest, and EEA conference in Toulouse. The comments and criticism of the editor, Prof. Simon Parker, and the three anonymous reviewers were of great value. All remaining errors are our own. This is cooperative work with equal share, and the order of names of the authors is alphabetical.
\end{abstract}

\section{Introduction}

Under deficient formal institutions, political connections are important for entrepreneurs who invest in building these connections either to protect themselves from expropriation or to gain access to resources (Zhou 2013; see also: Xu, 2011; Zhang, 2015). At the same time, the relative weight of these two aspects differs across emerging market economies. In particular, 
Puffer et al. (2010) contrast the institutional model of Russia with that of China. In Russia, the government is predatory, and entrepreneurs are in constant risk of expropriation. As a result, entrepreneurship remains weak, and the only businesses that thrive are those that are protected from expropriation by linkages with power structures (Ibid.; Aidis et al., 2008). In China, while expropriation can happen, it is an exception rather than the norm, because the government recognises the value of entrepreneurial initiative for development (Puffer et al., 2010). There, the critical way in which institutional weakness impacts entrepreneurs is not by the need for protection from expropriation, but by the time and effort they invest in seeking access to resources via cultivating relations with the government (Zhang, 2015).

Anecdotal evidence of this phenomenon abounds. Using Baidu (the popular search engine for the Chinese World Wide Web domains), we could identify a large number of commercial courses, case studies and tips for strategies and tactics offered to teach entrepreneurs how to "deal with" the government. Equally it is remarkable to see how many online businesses advertise their products related to government-public relations. Behind the prosperous markets for these services are the "consumers" - private entrepreneurs in particular; and one wonders how much effort they need to invest in their relationship with the government. Many stories in the Chinese media give clues. In one case, a famous entrepreneur (Feng Lun) complains "how exhausting and time-consuming it was to deal with government agents". Mr Lun, the President of Wan Tong Group, had to take flights 180 times in a year to make sure a project application was signed off by the government. ${ }^{1}$ Similarly, one of the most successful Chinese entrepreneurs, Liu Chuangzhi, the CEO of Lenovo, recalled that when his company was small, he had to spend more than $70 \%$ of his time and energy in maintaining relations with the "external environment", "governments in particular". ${ }^{2}$ In another article about government

\footnotetext{
${ }^{1}$ Source: Phoenix Media TV interview; http://finance.ifeng.com/business/renwu/20130128/7610444.shtml, as accessed on the $16^{\text {th }}$ of February, 2015.

${ }^{2}$ Source: http://management.yidaba.com/zhengfu/, as accessed on the 16th of February, 2015.
} 
subsidies, it becomes clear from many entrepreneurs' experience, that "getting subsidies is all about having a good relationship with the government, so you would get information in a timely manner and can access insiders to help with applications". ${ }^{3}$

This reality makes China a fascinating example for study of how institutional framework affects entrepreneurship. Learning from the failures of the state-centred development model, China started to drift away from it in the late 1970s (Huang, 2008; Lu and Tao, 2010; Zhang, 2015). China's drift was followed - about ten years later - by India and many other emerging market economies. Over the last three decades, China experienced unprecedented economic growth, and became the second largest economy in the world. The micro-foundations of this development relate to the build-up of domestic entrepreneurship, which came prior to the opening up of China to foreign investment (Huang, 2008; Lu and Tao, 2010; Coase and Wang, 2012; Nee and Opper, 2012). Correspondingly, in mainland China, economic dynamism originated from the emerging private sector companies and, to a great extent, this model of development drew upon the earlier experiences of various successful small economies dominated by ethnic Chinese businesses (Singapore, Taiwan, Hong Kong), as other neighbouring economies (like South Korea) were also directionally moving towards what Baumol et al. (2007) label as "entrepreneurial capitalism”.

Nevertheless, Chinese entrepreneurs were often in a disadvantageous position compared with the state sector, even if for much of the time since the reforms started, government policies were 'directionally liberal'; that is they enhanced opportunities for entrepreneurship (Huang, 2008; see also: Tsang, 1994; Zhao and Aram 1995; Lu and Tao, 2010; Coase and Wang, 2012). Success was possible because the gains from entrepreneurship were strong enough to

\footnotetext{
${ }^{3}$ Source: New Beijing News at http://epaper.bjnews.com.cn/html/2013-01/24/content_405802.htm?div=-1), access on the 16ht of February 2015.
} 
counterbalance various privileges in the access to finance and other resources that the state sector companies continued to enjoy (Lu and Tao, 2010; Zhang, 2015).

Although this process of liberalisation has not been uninterrupted (Huang, 2008) it does still continue; China has not yet achieved a stable institutional equilibrium. For development in China to be sustainable in the future, it is necessary to maintain the momentum of institutional reforms in building an inclusive market environment (Acemoglu and Robinson, 2012). Such reforms would see a pronounced shift from the uncertainty induced by the lack of transparent rules towards a strong rule-based system. While the government is no longer hostile to private enterprise, many instruments of state capitalism in China continue to interfere with business, including through the subsidising of firms in a non-transparent way (Haley and Haley, 2013). This is the focus of our paper.

Using subsidy is by no means exclusive to China. In fact, subsidies are common both in the developing world and in the developed economies. What is uncommon in the case of China, and hence attracting much interest, is that subsidies are spread over a large spectrum of firms and a broad range of sectors, and frequent changes in policies are observed (Haley and Haley, 2013). It is difficult to make sense of the patterns of Chinese subsidies, as there is no official document explaining the subsidising rules (Girma et al., 2009). While the government produces strategy documents that set up broad priorities for subsidisation, the actual nitty-gritty of these financial flows gives the external appearance of ad hoc interventions (Haley and Haley, 2013). As a result, government remains "the strongest stakeholder" (Tang and Tang, 2012), and for entrepreneurs, being able to access and influence those who distribute resources in the administrative and political hierarchy is an important resource (Zhang, 2014). Building these political connections requires allocating effort to unproductive activities. They are unproductive in the sense that while they generate gains for individual entrepreneurs, these 
gains result from resource redistribution, not from creating additional value. At the same time, the gains come with a deadweight cost (Baumol, 1996; Mueller, 2003; Zhang, 2015).

The institutional weakness we focus on does not result from the presence of the subsidies per se. Instead, it results from the lack of clarity in their distribution, which in turn creates scope for unproductive rent seeking activities by entrepreneurs. We posit that this lack of clarity is manifested by uneven distribution of subsidies among companies that are not dissimilar.

As we will argue below, while a direct individual effect of receiving a subsidy is positive, both the individual cost of rent seeking and the externality effects of others also receiving subsidies affect the average performance negatively, to the degree that in some cases these negative influences may well counterbalance the gains.

As the Chinese state sector continues to shrink, the unevenness in distribution does not only apply to the state-private axis. Some big and old private companies also enjoy political rents. Moreover, when government subsidies are unevenly distributed within the local business environment, the entrepreneurial sector (young, private and small companies) is affected in a different way to the old, state-owned and large firms. We will argue that although performance of private companies is disproportionally more affected by this than is the performance of state firms, the impact of government-induced uncertainty on young and small companies is actually less pronounced. This is because, compared to their old and big counterparts, the young and small companies face relatively high set-up costs of building government connections and of lobbying for government supports, which make them more reliant on a strictly private set of resources and networks at the initial stage.

Investigating these questions is not easy from the empirical point of view, as the lack of transparency leads to difficulty in finding detailed or complete statistics that provide a reasonably good overview of the phenomenon (Haley and Haley, 2013), and accordingly there 
is very limited research conducted on the topic. We are able to overcome this difficulty by testing our hypotheses based on a large firm level data set of 2.4 million observations over 1998-2008 that contains information on subsidy flows.

To summarize we see the key elements of our contribution in the following way:

First, as observed by Bruton et al. (2008, p.10), "the exact nature of institutional forces is not yet well conceptualized", in particular for emerging market economies. Addressing this, we focus on a specific mechanism of weak institutions - non-transparent government intervention through uneven distribution of subsidies. This stands in sharp contrast to most of the existing work that considers the aggregate level when modelling formal institutions, for example by measuring the broad characteristics of law and regulation, and informal institutions such as corruption or trust in a society. Such measures rarely go down to micro level and, when combined with firm- or entrepreneur-level analyses, the underlying assumption is that individuals receive homogenous effects from very broad and general institutional configurations. In our work, we challenge this perspective. We proxy institutional weakness via focusing on the patterns of subsidies' distribution on a highly disaggregate level. This gives texture to the theory on formal institutions' influence on entrepreneurs.

Second, the institutional economics and entrepreneurship literature seem to conclude that in transitional economies with underdeveloped institutions, the formal institutional voids are substituted with informal institutions, and some functional balance emerges between formal and informal institutions. Hence the focus of the debate is on the benefits of such institutional configurations, and not on the cost of it (e.g. Puffer et al., 2010). In contrast, we highlight the latter.

Third, through formal theorizing and empirical testing, we explain that weak institutions influence entrepreneurs' decisions to undertake unproductive versus productive activities, 
and we explore the firms' performance consequent to the corresponding behaviour. The direct focus on performance addresses a gap in the entrepreneurship literature identified by Chen et al. (2011).

\section{Theoretical framework}

\subsection{Level playing field, decentralisation and institutional quality}

Following Estrin et al. (2013) we define the quality of economic institutions by the extent to which the rule of law prevails in the economy. Institutions based on the rule of law are those that support level playing field for all economic actors, and for newcomers and entrepreneurs in particular, enabling them to both cooperate and compete on the market. However, extending this perspective, we argue that weak rule of law may be associated with at least two very different institutional contexts. The first of these is the case of predatory government. Aidis et al. (2008) and Puffer et al. (2010) discuss its implications for entrepreneurship. A formal model of such an environment has been presented by Parker (2009) extending and clarifying earlier work by Murphy et al. (1993).

In this paper however, we focus on a different case: that of a government which does not behave in a predatory manner but its role in resource reallocation does not follow a clear set of rules and procedures. Universal rules do not apply. They are replaced by selective and arbitrary distribution of resources. This creates uncertainty for entrepreneurs. As the rewards are defined by the government, the incentive structure leads entrepreneurs to invest effort into unproductive influence and rent-seeking activities.

Below, we offer a simple formalisation of such a context and, in the empirical section, apply this perspective to China, to investigate the microeconomic performance implications of these phenomena. What makes China an interesting case study is the degree of regional 
heterogeneity in its institutional environment (e.g. Tsang, 1994; Bruton and Ahlstrom, 2003; $\mathrm{Xu}, 2011)$. Unlike the former Soviet Block, which drew on the same set of ideological beliefs, China was always decentralised across its territory (Xu, 2011), and this became a key characteristic that from the late 1970s facilitated a gradual shift towards a more functional institutional model, relying upon local institutional entrepreneurship and institutional diffusion over space (Weingast, 1995; Coase and Wang, 2012; Zhang, 2015).

Decentralisation implies that institutional quality differs across Chinese regions. In some areas, similar companies face similar treatment by the government, while in some others they do not. Building on this observation, we argue the following: First, where the subsidies are distributed in a more uneven way, the average company's financial performance will be lower, due to additional (rent seeking) influence costs. Second, we expect some categories of companies to be more negatively affected than others. In particular, the implications for the entrepreneurial sector may differ: we contrast private companies with state owned companies, large companies with small companies, and old companies with young companies. We will discuss all these points in turn and summarize our arguments with a simple formal model.

\subsection{Weak institutions and firms' profitability}

Figure 1 below presents the basic framework we apply. We provide the main intuitions first; then in the remaining part of Section 2 we elaborate on details. In Section 3, we present the algebra that generates Figure 1, and finally we summarize the discussion with hypotheses.

We first notice that if government policy is effective, mean profitability in a given group of companies should increase with the number of firms receiving subsidies: financial support for a particular sectoral-regional activity implies additional profit for companies. Mean profitability should increase, even if some of the additional cash is shared with owners of local 
resources that the companies are bidding for against each other. We label this case "Effective Intervention" (Scenario A). In a Pigouvian world of efficient and benevolent government, this is the only case that is possible (Pigou, 2001 [1924]).

Yet, as we know from the entrepreneurship literature (Parker, 2009), companies may be more than just production functions, mechanically manipulated by government administrators endowed with perfect foresight. Moreover, there may be information asymmetry, with administrators knowing less about companies than their owners or managers. Even if the information were available, the administrators are characterized by bounded rationality. And their objectives may be difficult to translate into a clear blueprint for intervention. Finally, their motivation may be problematic, as their private interests may interfere with those public interests they are expected to represent. It is sufficient that only some of these phenomena are present to create space for influence activities (rent seeking) by firms' managers. In which case, the effects of intervention become very different.

In particular, we distinguish between the following two outcomes: "Counterproductive Intervention" (Scenario B) and "Non-transparent Government" (Scenario C). Under Scenario $\mathrm{B}$, the positive impact of subsidies is always offset by rent seeking cost, competition for rents results in profits from rents being driven down to zero, and subsidies have no (mean) impact. This scenario is well known from the literature (Posner, 1975), therefore we do not elaborate upon it.

In contrast, under Scenario C, it is the lack of transparency in subsidies' delivery that matters. As most of the political economy / public choice theory relates to developed market economies (e.g. Mueller, 2003), it comes as no surprise that we found no references in the literature to such a model. We argue below that Scenario C is more likely in the case of China.

Under Scenario C, there are two polar cases depicted in Figure 1 below. On the far left, no firm in a given category receives subsidies. On the far right, subsidies are distributed according 
to transparent rules and therefore all similar firms are equally subsidised. What these two situations have in common is that similar firms are treated in a similar way. As a result, applying Kornai's (1986) terminology, the effort of managers, responding to any changes in market conditions, is focused on the "productive sphere" not on the "control sphere", as there are no gains to be made from the latter. In contrast, where the rules are not clear and a company may or may not receive support, the "control sphere" becomes critical:

"In the first case the firm reacts in the real sphere and in the second case in the control sphere. In the first case it acts in the factory and in the second case in the offices of the ministry, tax authority or bank. In the first case the main element of reaction is production - the adjustment of the input and output combination to the new situation. In the second the main elements are requests, complaints and bargaining - in other words, attempts to manipulate those on whom tax remissions, subsidies, soft credit, and so on depend.” (Kornai, 1986: 43; italics as in the original text).

Consequently, time and energy, which are managerial resources, are spent on establishing and maintaining a relationship with local governments, regulators or bankers, which is what Baumol (1996) labels as unproductive activity. Where the system of government subsidies' distribution is the least transparent, these rent seeking activities will also be the highest. It is there that the positive (mean) effects of subsidies will be counterbalanced by costs of rent seeking via 'control sphere' activities.

Taken together, this leads to the U-shaped curve as illustrated by Case C on Figure 1 below, but we postpone the formalization of this idea to Section 3. Before that, we intend to introduce an additional angle, and posit that the effects we just discussed will affect different types of companies in a different way, making it a useful framework for entrepreneurship theory, as we focus on the companies' attributes used to operationalize entrepreneurship (Parker, 2009). 


\subsection{Uneven playing field: private versus state companies}

Hellman et al. (2003) and Driffield et al. (2013) argue that - contrasted with private firms state firms find influencing the government more easy, particularly in weak institutional environments. State firms can rely on direct links with the state administration, hence they do not need to invest heavily in rent seeking. As argued by Zhang (2015), they are "fullmembership rent-seekers" (Ibid., p.133). In contrast, private entrepreneurs need to create relational capital with administrators and politicians in order to gain access to resources. This pattern is characteristic of all partly privatised, partly reformed economies, where entrepreneurs need to engage in rent seeking to match the state sector advantages (Mickiewicz, 2009). The less transparent the government is, the more likely it is that the influence costs of the private companies will be higher compared with those incurred by state companies.

In the Chinese context, this is further facilitated in the case of state companies by a larger overlap between the managerial positions and political affiliation ( $\mathrm{Lu}$ and Tao, 2010). Moreover, for many state firms' managers, their enterprise is "a springboard for becoming bureaucrats" (Zhang, 2015, p.220), again indicating a close relation between the spheres of state sector firms and state administration.

With regard to China, Nee and Opper (2012) notice two features of state firms that contrast with private companies: egalitarian wage structures and guarantees of lifelong employment (see also: Shleifer and Vishny, 1994; Frydman et al., 1999; La Porta and Lópes-de-Silanes, 1999). In addition, there is extensive profit diversion by managers for private gain (Zhang, 2015). This implies that while state firms are more likely to become addressees of state support, the profitability of state firms will not vary with subsidies, as the support is likely to be matched by the diversion of resources away from profit maximisation and towards both employees and managers. 
More generally, due to the lack of property rights, those who control the state firms cannot separate distributional decisions from optimisation decisions; and that affects performance. Additional resources provided by the government are shared as rents by the managers and the workers. Again, this argument suggests that the profitability of state-owned enterprises (SOEs) will be less impacted by the extent of subsidies.

In contrast, private enterprises are often found to be unable to operate under the same business conditions and with the same policy treatments as the state-owned firms and foreigninvested firms (Huang, 2003). They are less able to access key factors of production including land (Chen et al., 2011) and formal finance (Allen, Qian, \& Qian, 2005). They also endure unfair treatment such as higher tax rates (Chen et al., 2011; Du et al., 2014), in particular when there are fiscal deficits (Chen et al., 2011). In response to these constraints, private enterprises can be seen developing and exploiting their relational social capital with government officials, bank officials, and executives at other firms (Tsang, 1994; Zhao and Aram, 1995; Du and Girma, 2010; Cai, Fang and Xu, 2011; Du, Guariglia, and Newman, 2013), with the aim of circumventing their unfavorable status. Yet, as we argued above, the importance of these activities distorts managerial time allocation, driving it away from the focus on value creation towards control sphere (Zhang, 2015).

Moreover, owners and managers of firms (particularly private firms) operating in a weak institutional environment are cautious about reinvesting their profits and instead channel more resources towards consumption (Tsang, 1994). This is because the policy uncertainty they face erodes the value of the expected return on investment. At the same time, firms' growth and sustained profitability crucially depends on profit being ploughed back into the business; hence it is reasonable to assume that the resulting overly cautious investment behaviour may also have a negative impact on profitability. 


\subsection{Large versus small; old versus young}

While the Chinese state sector is still large, the private sector is growing faster. The number of individually owned businesses has increased from 98,000 in 1978 to 10.9 million in 2010, just about 110-fold. The last decade has seen high growth in the private sector's turnover by more than $30 \%$ and the contribution of one-third of GDP and four-fifths of all the new jobs (Du et al., 2014). Much of the empirical literature on China, as already cited, interprets private ownership as the characteristic that defines the extent of the entrepreneurial sector. Without denying it, we postulate that a finely-graded distinction between the small versus the large, and (even more so) between the young versus the old is important. As we will argue below, the implications of the institutional weakness for young and small companies may differ from the general implications for the private sector.

Nee and Opper (2012) provide evidence showing that small companies are under the radar screen of local politicians. In contrast, politicians and administrators actively seek contact with large companies, and are more responsive to requests coming from large companies' managers. As a result, while it is relatively easy for the managers of large companies to establish cosy relationships with local politicians; the managers of small companies are unlikely to be welcomed in the inner circles of the local political capitalism networks. A pattern like this would suggest that entrepreneurs running small companies invest less time and effort in building relational capital with the government than their larger company counterparts.

In addition, there may be fixed costs of lobbying for government support. Lobbying implies establishing social contacts and offering gifts to politicians and public administrators. These gifts can come in the form of socially acceptable private transfers (e.g. hospitality), illegal transfers (bribes), or as support for public causes prioritised by the administrators (charity) (Tsang, 1994; Xin and Pearce, 1996; Huang, 2008; Du et al., 2013). At the same 
time, politicians face time and attention constraints, hence larger transactions are likely to be prioritised. That again makes the phenomenon of rent-seeking more characteristic in resource-abundant firms, which tend to be larger in size.

Some of the arguments related to the size of firms are easily extended to the age of firms. Just as with small firms, young firms are likely to operate under the radar screen of local politicians; moreover, these two aspects - size and age - are related in an obvious way. Thus, returns for rent seeking efforts by young firms should also be lower than those of old firms.

However, while firms are typically born small, the impact of size and age on the intensity of rent-seeking may also differ. As highlighted by Olson (1982), for any organisation, rent seeking effects are amplified only over a longer period of time, and this argument can easily be applied at the micro level of an entrepreneur dealing with local administrators. In particular, new firms are in the process of building their resources and capabilities base, and in the initial phase they may rely more on their private networks (Nee and Opper, 2012) than on networking with the formal institutions as represented by the government. This makes them less sensitive to the formal environment.

\section{Simple formalisation and hypotheses}

We now move on to summarize some of the intuitions discussed above in a simple formal model. Inevitably, some aspects of the discussion above will be left aside, and our focus will only be on a few core elements.

We envisage a sector that consists of a number of companies that may sell a similar product on a global market but are competing against each other in local markets for inputs. Some companies receive subsidies, while others do not. We assume that for each company that receives a subsidy, the value of the subsidy is identical. The probability of receiving a subsidy varies with the company's rent seeking effort. The percentage of companies that are 
awarded subsidies is exogenously given (decided by the public budget's holder), and is defined by $n$.

Let's us next define $R_{i}$ as the expected value of the subsidy (rent) that a company $i$ gains; and $I_{i}$ as the influence cost incurred by the company in order to gain that subsidy. Then supposing the representative company is risk-neutral, we summarize our assumptions about the way the expected income $\left(Y_{i}\right)$ of the company from rent seeking is determined, in the following way:

$$
\begin{aligned}
& E\left(Y_{i}\right)=R_{i}-I_{i}-\alpha n R_{i} \\
& E\left(R_{i}\right)=\beta n \ln \left(I_{i}\right)
\end{aligned}
$$

where $\alpha$ and $\beta$ are parameters and

$$
R_{i} \geq 0 ; I_{i} \geq 0 ; 0 \leq n \leq 1 ; 0 \leq \alpha \leq 1 ; \beta>0
$$

Parameter $\alpha$ corresponds to the magnitude of the negative externalities resulting from the fact that when a larger share of companies in a given local market receive subsidies, they will compete more for local inputs, driving up some costs. Parameter $\beta$ relates to the 'rent production function' and captures the expected rate according to which the expenditure on the influence is transformed into rents from the subsidies. For rent seeking to be present, it needs to exceed zero. The use of the natural logarithm in this function corresponds to the idea that there are diminishing returns from rent seeking (influence) activities. In turn, $n$ appears in equation (2), because with the larger (exogenously given) share of companies that are awarded subsidies in the local market, the pool of awards increases. 
The critical assumption behind the equations (1) and (2) is that the overall magnitude of subsidies is not so large that the (local) government hits its budget constraint. If the latter were the case we would have to consider a model where the average size of an individual subsidy varied inversely with the share of companies receiving subsidies. In the empirical section below we will provide evidence that this scenario does not seem likely.

Substituting from equation 2 back into equation 1, taking the first derivative, and dropping the expectation operator for convenience, we obtain:

$$
\frac{\partial Y}{\partial I}=\frac{\left(n-\alpha n^{2}\right) \beta}{I}-1=0
$$

And therefore the optimum amount of investment into influence (rent seeking) becomes:

$$
I^{*}=\beta\left(n-\alpha n^{2}\right)
$$

That implies that the optimum amount of investment in rent seeking is likely to vary with the share of firms receiving subsidies in the local market in a non-monotonic way.

Substituting equation (4) back into the income function equation (1), we obtain:

$$
Y_{i}^{*}=\beta\left(n-\alpha n^{2}\right)\left\{\ln \left[\beta\left(n-\alpha n^{2}\right)\right]-1\right\}
$$

This is non-monotonic in $n$, the share of firms in the local market receiving subsidies. For the combination of parameters where $\alpha$ is not high relative to $\beta$, it results in a U-shaped function parallel to the scenario C (of arbitrary government) in Figure 1 above. The restriction on parameters is intuitive, because $\beta$ represents the individual-level productivity of rent seeking effort, and $\alpha$ corresponds to negative externalities of rent seeking experienced at 
the individual level. Clearly, high $\alpha$ with respect to $\beta$ could imply that negative externalities from rent seeking exceed the expected gain, causing the logic of the model to collapse.

Consistent with this, we posit:

H1. The proportion of firms receiving the subsidies in a given local market will affect mean profitability in a non-monotonic, U-shaped manner.

Now, as discussed in the previous section, we expect the returns to rent-seeking investments to be higher for managers of both older and larger companies compared to entrepreneurs. We may introduce it back into our model by assuming that we now have two types of companies. For Type 1 companies, we have $\beta_{1}>0$. For Type 2 companies we have $\beta_{2}=0$ and they neither invest in rent seeking nor do they receive any subsidies. Since Type 1 companies invest in rent seeking, optimization for them follows the similar logic as before, except that now the expectation has to account both for the proportion of firms that will actually receive subsidies ( $n$, as before) and the proportion of firms that are of Type 1 (i.e. they can receive subsidies; denoted by $m$ ). Accordingly, instead of equation (1) we now have:

$$
E\left(Y_{i}\right)=R_{i}-I_{i}-\alpha \frac{n}{m} R_{i}
$$

Following the same logic as before, we obtain the expected income for Type 1 companies:

$$
Y_{i}^{*}=\beta \frac{n}{m}(1-\alpha n)\left\{\ln \left[\beta \frac{n}{m}(1-\alpha n)\right]-1\right\}
$$

All this holds, as long as $n$, the share of companies receiving subsidies (decided exogenously) is lower than the share of the companies that can receive subsidies (Type 1), $m$. In turn, Type 2 companies, which do not engage in rent seeking, are still affected by the negative externalities, and their income becomes a negative linear function of revenue of rent seeking that the Type 1 companies obtain. Accordingly, for them, equation (1) now reduces to: 


$$
E\left(Y_{j}\right)=-\alpha n R_{i}
$$

It follows that we have the non-monotonicity in $n$ for Type 1 companies, which are the only ones that invest in rent seeking. In contrast, for Type 2 companies present in the sector, profitability will decease monotonically with $n$ due to negative externalities produced on the local input markets: income of Type 2 companies will still be affected by $\alpha n R_{i}$. Therefore:

H2: The non-monotonic (U-shaped) effects of the proportion of firms receiving the subsidies in a given local market are stronger on large companies compared with small.

H3: The non-monotonic (U-shaped) effects of the proportion of firms receiving the subsidies in a given local market are stronger on older companies compared with younger.

Finally, in order to explain the difference between state-owned and private companies, we need to introduce ownership-specific effects. As argued above, state companies have close ties with the government and receive subsidies with little effort. Simplifying it for the sake of modelling, we may say that investment in influence becomes spurious for state companies. They do not invest in rent seeking, but for a very different reason to small and young companies, as discussed above. We capture this by introducing a new parameter $\gamma$ into the rent production function, and by making both $\gamma$ and $\beta$ vary with ownership characteristics $O$ : $S$ corresponding to the state sector, and $P$ corresponding to the private sector, so that:

$$
\begin{aligned}
& \gamma_{O}>0 \text { if } O=S ; \gamma_{O}=0 \text { if } O=P \\
& \beta_{O}=0 \text { if } O=S ; \beta_{O}>0 \text { if } O=P
\end{aligned}
$$

Equation (2) becomes: 


$$
R_{i}=\beta_{O} n \ln \left(I_{i}\right)+\gamma_{O}
$$

It is easy to verify that solving this new model results again in equation (5) for private companies, as $\gamma$ plays no role in the optimization. However, with $\beta=0$, state companies make no investment in rent seeking. On the other hand, their income from subsidies is always positive and simply given as $\mathrm{Y}^{*}=\gamma$. There is no longer any non-monotonicity associated with $n$.

In contrast, for private firms, the optimization corresponds to the equation (5) as before. Again, we obtain non-monotonicity in $n$, due to the interaction of $\beta$ with $n$. Therefore, we receive:

H4: The non-monotonic (U-shaped) effects of the proportion of firms receiving the subsidies in a given local market are stronger for private companies than for state companies.

\section{Data, summary statistics and definitions of variables}

\subsection{Data}

We conduct the empirical analysis based on the Annual Reports of Industrial Enterprise Statistics, compiled by the National Statistical Bureau of China (NSB) over the period of 19982008. The NSB strives to ensure consistency in data collection across geographical regions and industries, and audits a selection of firms to ensure accuracy of the financial data (Tan and Peng, 2003). The data covers the population of SOEs and non-state owned firms with annual sales above 5 million RMB, which makes it the most comprehensive firm level dataset available for China; it has been recently adopted in the research on Chinese firms (for example 
Du and Girma, 2007; Brandt et al., 2013). These firms operate in the manufacturing and mining sectors and come from all 31 provinces or municipal cities across China.

Several advantages of this dataset over others are crucial for the purpose of this study. First of all, the population of the SOEs and the complementary data of non-state owned enterprises account for $85-90 \%$ of total output in most industrial sectors, which permits a highly representative description of the industrial dynamics. The rare comprehensive data coverage, across firms and over time, allows us to build a profile of firms of different ages and to observe their performances over the decade. Second, the close-to-population firms' coverage makes it possible to study the external effects of government subsidies.

The final data matrix was subject to careful cross checking and cleaning, and we paid particular attention to ensure the consistency of firm identification, industrial concordances and ownership classification (for more details see also: Du et al., 2014). The observations with negative or zero employment records were dropped, as were those with negative assets and intermediate inputs. The variables of interest have been trimmed by $1 \%$ on each side of the distribution. After cleaning out the observations with missing values in the variables of interest, we identified 662,805 firms corresponding to 2,399,047 firm-year observations over the period 1998 and 2008, for which we have the necessary information for the econometric estimation.

\subsection{Variables}

Table 1 presents the descriptive statistics of the variables of interest. The dependent variable, profitability, is the commonly used indicator of Return on Assets (ROA), calculated by dividing total profit over total assets.

<Insert Table 1 here > 
In order to test our hypotheses, we need a measure of distribution of subsidies over a given cluster of firms. We capture the dispersion in firm subsidies in two slightly different ways to describe how stretched or squeezed the distribution of subsides is. We first construct a simple measure of subsidies' coverage ratio (Cov) defined as a share of subsidised firms' $(i)$ assets in overall assets, where the latter are aggregated over each cell defined by: six-digit geographic region equal to county level $(k)$, two-digit industrial sector $(j)$, and year $(t)$ :

$$
\text { coverage }_{j k t}=\frac{\sum_{i}\left(\text { Total assets }_{i j k t} \mid \text { subsidy }_{i}>0\right)}{\sum_{i} \text { Total assets }_{i j k t}} .
$$

This measure describes the weighted share of subsidised firms in the local population of firms, where the latter is defined by regional-sectoral-annual cells. According to our calculation, on average, $22 \%$ of firms (weighted by assets) across all cells (of county, industry and year) received government subsidy. In addition, the standard deviation of $28 \%$ and the full range of coverage ratio value (0 1) show that the cell heterogeneity is also large. Some industries in some locations and in some years received many more subsidies than others.

The second measure of subsidy distribution is a commonly used measure of statistical dispersion, the median absolute deviation (mdev), which is a strongly robust measure of the variability of a univariate sample of quantitative data (Rousseeuw and Croux, 1993):

$$
\operatorname{mdev}_{j k t}=\operatorname{median}\left(\left|\operatorname{subsid}_{i}-\operatorname{median}_{j k t}\left(\operatorname{subsidy}_{j k t}\right)\right|\right) .
$$

Again, we calculate this measure for each cell of a region, an industry and a year, and then scale down the value of mdev by 100 . The variable shows as high standard deviation as the first measure. 
Both measures are informative on the subsidy distribution among firms in the defined cells, but they have slightly different foci and hence may be seen as complementary. We build our analysis on both measures as each of these have potential limitations. The coverage ratio captures the percentage of activity being subsidised as proxied by total assets, but here the larger number of super-sized firms in a cell may increase the coverage ratio. In the latter case, the higher coverage does not necessarily mean wider coverage of subsidies in the local population of firms. In turn, the mdev measure describes the dispersion in the amount of subsidies among firms. But since it does not take into consideration the number of the subsidy recipients, a high $m d e v$ dispersion does not always imply more uneven distribution, as it may be affected by uneven firm size distribution within the cell. Nevertheless, a simple partial correlation test shows high correlation of $60 \%$ between these two measures, as reported in Table 2.

Both of the subsidy coverage variables that are constructed at county/sector/year cell level do not vary between firms within each cell, but do vary across 6-digit region (county level), 2digit industrial sector and year. It is not surprising that the total variance of coverage variables is dominated by industrial variation more than regional differences, and the patterns are stable over time. $^{4}$

<Insert Table 2 Here>

Our Hypotheses 2 and 3 relate to corresponding interactive effects of age and size with distribution of subsidies. We also include the individual effects of these components directly

\footnotetext{
${ }^{4}$ We investigated the distribution of coverage across sectors and regions using the basic variance decomposition technique, and find that at the cell level, less than one-third of total variance is due to the regional differences, while about two-third comes from industrial differences. The figures are stable over time. Detailed results are available upon request.
} 
in our models, in addition to their interactions. Over 1998-2008, the average age of firms is 11 years. The average firm size is 108 employees, yet firm size displays large heterogeneity.

In order to test Hypothesis 4, in this paper we classify firm's ownership by its official registration records. The final dataset is comprised of nearly $10 \%$ of state-owned firms, $15 \%$ of collectively owned firms, $15 \%$ share-holding firms, $40 \%$ private firms and $21 \%$ foreigninvested firms.

It is interesting to explore how our dependent variable is partitioned by the ownership cross section. State companies tend to be loss making, with the mean ROA at $-1 \%$. In contrast, for the collective enterprises mean ROA is $9 \%$, for shareholding companies it is $7 \%$, for foreign companies $6 \%$ and finally it is an impressive $13 \%$ for private firms. All these differences are highly significant when the means are tested against each other using $t$ test.

Finally, we control for market concentration ratio applying Herfindahl-Hirschman index (HHI). It is calculated as $\mathrm{HHI}=\sum_{i=1}^{N} s_{i}^{2}$, where $\mathrm{s}_{\mathrm{i}}$ is the market share of firm $i$ and $\mathrm{N}$ is the total number of firms in industry $j$. Thus $\max (\mathrm{HHI})=1$, when there is a single monopoly producer, while $\min (\mathrm{HHI})=1 / \mathrm{N}$ when the industry consists of $\mathrm{N}$ equal-sized firms. HHI depicts the market structure better than the concentration ratio (Stigler, 1964).

\subsection{Empirical specification and estimation methodology}

For the sake of transparency, we start with a model where profitability of a firm is regressed on the subsidies' coverage (linear term only) and controls as discussed in the previous section. Thus, we specify a profitability function in the following form:

$$
\pi_{i t}=\alpha+\beta^{\prime} \operatorname{Cov}_{i t}+\chi^{\prime} X_{i t}+v_{t}+v_{i}+\varepsilon_{i t},
$$


where $i$ indexes firms, $t$ denotes year and $\pi$ denotes firm profitability that is the dependent variable (ROA). The function includes a time-specific component $\left(v_{t}\right)$, an individual firm fixedeffect term $\left(v_{i}\right)$, and an idiosyncratic error term $\left(\varepsilon_{i t}\right)$. The $v_{t}$ element of the error term takes into account the macroeconomic environment factors. The $v_{i}$ element captures all time-invariant firm level fixed effects that may determine firm profitability. It is worth noting that the industrial sector and regional characteristics that stay constant over time are already included in the firm level fixed effects.

As mentioned above, in addition to the core independent variables, three variables that appear in the previous literature and are commonly employed in explaining firm profitability are also included in our model as control variables (in vector $X$ above). The natural logarithm of total employees is used to measure firm size, and is expected to be positively related to profitability. Firm age is measured as the number of years since the firm was initially established, and is expected to be positively related to profitability.

Our main interest is to investigate how uneven distribution of subsidies affects firm's profitability and, based on the theoretical discussion, we expect that Model 1 above is misspecified in that the square term is missing. In particular, a more even distribution of subsidies takes place either where the number of firms receiving subsidies is large, or where the coverage is very high. It is in the middle of a given region-sector cell where we face a polarisation: numerous companies receive support while many others are left out; this defines the most uneven playing field. Accordingly, we expect the sign of the linear term in coverage to be negative and the sign of quadratic term to be positive, consistent with Hypothesis 1. This corresponds to our Model 2:

$$
\pi_{i t}=\alpha+\beta^{\prime} \operatorname{Cov}_{i t}+\gamma^{\prime} \operatorname{Cov}_{i t}^{2}+\chi^{\prime} X_{i t}+v_{t}+v_{i}+\varepsilon_{i t}
$$


This is our benchmark specification. To test our Hypotheses 2-4 we next augment this model with interaction terms between the coverage and age size and ownership variables. This produces Models 3 -5:

$$
\begin{aligned}
& \pi_{i t}=\alpha+\beta^{\prime} \operatorname{Cov}_{i t}+\gamma^{\prime} \operatorname{Cov}_{i t}^{2}+\varphi^{\prime} \operatorname{Cov} * A g e_{i t}+\kappa^{\prime} \operatorname{Cov}^{2} * A g e_{i t}+\chi^{\prime} X_{i t}+v_{t}+v_{i}+\varepsilon_{i t} \\
& \pi_{i t}=\alpha+\beta^{\prime} \operatorname{Cov}_{i t}+\gamma^{\prime} \operatorname{Cov}_{i t}^{2}+\varphi^{\prime} \operatorname{Cov} * \operatorname{Size}_{i t}+\kappa^{\prime} \operatorname{Cov}^{2} * \operatorname{Size}_{i t}+\chi^{\prime} X_{i t}+v_{t}+v_{i}+\varepsilon_{i t} \\
& { }_{i t}=+{ }^{\prime} \operatorname{Cov}_{i t}+{ }^{\prime} \operatorname{Cov}_{i t}^{2}+{ }^{\prime} \operatorname{Cov} \operatorname{Coll}_{i t}+{ }^{\prime} \operatorname{Cov}^{2} \operatorname{Coll}_{i t}+{ }^{\prime} \operatorname{Cov} \operatorname{Shar}_{i t}+{ }^{\prime} \operatorname{Cov}^{2} \text { Shar }_{i t}+ \\
& \text { 'Cov Prit } i_{i t}{ }^{\prime} \operatorname{Cov}^{2} \operatorname{Pr} i_{i t}+{ }^{\prime} \operatorname{Cov} F{ }_{i t}+{ }^{\prime} \operatorname{Cov}^{2} \mathrm{For}_{i t}+X_{i t}+{ }_{t}+{ }_{i}+{ }_{i t} \\
& { }^{\prime} \operatorname{Cov} \operatorname{Pr} i_{i t}+{ }^{\prime} \operatorname{Cov}^{2} \operatorname{Pr}_{i t}+{ }^{\prime} \operatorname{Cov} F_{0 o r}+{ }^{\prime} \operatorname{Cov}^{2} \mathrm{For}_{i t}+{ }^{\prime} X_{i t}+{ }_{t}+{ }_{i}+{ }_{i t}(5)
\end{aligned}
$$

Size and age as well as ownership variables are also included in vector $X$ of control variables; this is not spelled out above for the sake of brevity. Ownership features in the interaction terms, and State Sector is the omitted benchmark variable, Coll relates to collective enterprises, Shar denotes shareholding companies, Priv relates to private firms (our key category of interest) and For to foreign firms.

In addition, we test all these models utilising an alternative form of the variable representing subsidy distribution, namely the second measure described above: $M d e v$. This corresponds to Models 6-10 as presented below in the Results section. For each model specification, a joint significance test is conducted to inform its appropriateness.

All equations are estimated using a fixed effects panel estimator, corrected by applying robust standard errors clustered on regional-city per year. ${ }^{5}$ The fixed effect estimator deals, to

\footnotetext{
${ }^{5}$ It is useful to explain that in this paper "county" means county and county-city. County-city differs from regional-city in its administrative level. In China, the administrative level immediately below a province is "regional city". "County city" refers to cities that are at the same levels of counties, and many of them were
} 
some extent, with unobserved heterogeneity and potential endogeneity in the model. ${ }^{6}$

Hausman tests were conducted both to test the endogeneity of fixed effects, and to verify the adoption of panel fixed effects estimator over random effects estimator (Wooldridge, 2002).

\section{Results}

All the estimation results are reported in Tables 3 and 4 below, where Table 3 relates to Models 1-5, and Table 4 to Models 6-10.

\section{<Insert Tables 3 and 4 here>}

As discussed above, when we apply only the linear term of coverage ratio of subsidies (Coverage), we may face a model misspecification bias (Model 1). Nevertheless, this is a useful test of an effective intervention model as depicted on Figure 1 above (Cases A). In this specification Coverage is highly insignificant with a coefficient effectively estimated as zero, which implies no support for the Pigouvian scenario. However, as soon as we add the quadratic terms (Model 2), consistent with Case $\mathrm{C}$ of the impact of non-transparent government, both coefficients of Coverage become significant, supporting Hypothesis 1 . As we expected, there is a U-shaped relationship between subsidy coverage ratio and average firm profitability. When the coverage is very small the average profitability is high, and the level of profitability drops as the coverage ratio increases, up to a certain point. After the turning point, the average firm profitability increases with further increase of subsidy

counties before becoming cities. They are practically administrated by regional cities. Our subsidy coverage variables are generated at county/county-city level to capture the regional heterogeneity, and clustered standard errors at regional-city per year level allow correlation of residuals of countries located in the same regional-city. ${ }^{6}$ The fixed effects estimation is conducted using reghdfe routine in Stata 14 (Correia, 2014). 
coverage. Moreover, according to Model 2, the turning point is near the middle of the distribution, as we expected.

The pattern of the effect of subsidies' coverage on profitability varies clearly with ownership. From the coefficients presented in Model 3 we can see that the expected nonlinear effect of subsidies' coverage is highly amplified for private firms, as expected; supporting Hypothesis 4 . This is also easy to see from Figure 2 below. The shape of the effect clearly changes with ownership, and the difference between the private domestic companies and all others is striking.

\section{<Insert Figure 2 here>}

In Model 4 we add the interaction effect between the size of firm and the subsidies' coverage to test Hypothesis 2. Again, the size absorbs significance and amplifies the expected nonlinear effect of subsidies' coverage. While the second (quadratic) term is insignificant, both terms remain jointly significant based on t-test. Moreover, both linear and quadratic term in interaction with size are highly significant when we use our alternative measure of coverage (mdev; in Table 4). To see the magnitude of effects more clearly, we present them in Figure 3. The three alternative levels of employment chosen to illustrate the effects are one standard deviation below the mean (30 employees), near the mean (100 employees) and one standard deviation above the mean (300 employees). Note that for the sake of Figure 3, we exponentiate back the logarithm of employment (a form used in estimations) to facilitate interpretation. For companies at mean sample size and larger, the effect of subsidies' coverage is U-shaped. However for small companies it is more like reversed L-shaped: they are not much affected until the coverage increases above 50\%, when they start to benefit. This suggests that there may be a 'pecking order' of subsidies' distribution, where large 
companies receive support first. Only when a large number of companies have been included in subsidies distribution, do the small companies take advantage.

\section{<Insert Figure 3 here >}

In Model 5 we add the interaction term of Coverage and Age to test the Hypothesis 3. What happens is that the interaction with age absorbs most of the explanatory power, as easily seen from the corresponding significance levels. Age clearly amplifies the nonlinear effect of subsidies' coverage on profitability. To understand the way the interaction works we plot the marginal effects of the subsidies' coverage for different levels of age at Figure 4 below. Again, we pick up three values of age to illustrate the interactive effect: one standard deviation below the mean (1 year old companies), at the mean (10 years old) and one standard deviation above the mean (20 years old). The pattern that emerges is the following: profitability of companies that have just started (when age equals 1) is simply not affected by the distribution of subsidies. If anything, there is a slight upward linear trend, parallel to what we observed for companies of small size, above. This may indicate again a 'pecking order' in subsidies, where the youngest companies benefit only after the older ones are covered already. However, the effect of Coverage becomes mildly nonlinear and U-shaped for firms at the mean age of 10 , and more clearly $\mathrm{U}$-shaped for companies 20 -years old. This is consistent with our Hypothesis 4. Interestingly, new companies seem to be more profitable than old, as can be easily assessed by the position of the corresponding curves on the graph: a simple correlation between age and profitability is $-13 \%$ and it does not disappear in the regression model, even if we control for ownership differences. 
Table 4 replicates models of Table 3, but this time we use Mdev as our measure of subsidies' distribution. The results seem qualitatively the same as in Table 3 . The benchmark model (6, similar to 2$)$ for overall firms yields the same nonlinear pattern, however the quadratic term is now insignificant. Interactions with both age and size are again highly significant and the effects work the same way as before. Likewise, the results for interaction with private ownership support Hypothesis 4.

\subsection{Robustness checks}

The fixed effects (FE) estimator we apply to our specifications is consistent but may not be efficient. We also run the random effects (RE) version of our models; nevertheless we found, using the Hausman test, that the FE models should be relied upon. In addition, while the RE model can be seen as the simplest form of multilevel modelling, we also apply a more complex multilevel model, which contains three levels: individual observation in a given year; firm level random effect; and sector-region random effect. Furthermore, we experimented on controlling for different levels of clustering the standard errors. Besides the results reported in our baseline model where we cluster the standard errors by region-city per year, we also tried clustering the standard errors by province per year, regional-city per year per sector. The results were again not affected.

The main objection that can be raised against our modelling is that we do not include any direct rent seeking measures, yet assume rent-seeking in between uneven distribution of subsidies and performance outcomes. The reason we followed that strategy is not because such measures are not available. In fact, in the Chinese context, entertainment and gift giving expenditure have been used as a measure of rent seeking (e.g. Du et al., 2013; Cai et al., 2011), and we have this variable in our dataset. However, the difficulty in modelling lies in 
the fact that performance is affected both directly by the quality of the institutional/policy context and indirectly by rent seeking, which in turn is endogenous vis-à-vis the institutional/policy environment. Thus the equations we report can be seen as reduced form specifications, whereby we regress performance on our proposed measures of the quality of institutional/policy context, which we take as exogenous with respect to individual profitability. However, as a robustness check, we also run specifications where we add rent seeking expenditure and its squared term. As expected, we find highly significant and positive effects of rent seeking on profitability (in both linear and square terms), indicating some basic rationality in the way the entrepreneurs and managers behave. Importantly, our results for subsidies' coverage are not affected.

In addition, we also estimated the likelihood of receiving subsidies as a function of rent seeking, with the same set of variables we use in our core models of profitability plus coverage of subsidies, applying both a fixed effects (FE) and a random effects (RE) logit model. For rent seeking taken in logarithmic form, which corresponds to the functional form we used in our formal model, the coefficient is significant at 0.001 and positive for both models, suggesting diminishing returns to rent seeking. Likewise, a specification with rent seeking in linear and quadratic term results in positive linear and negative quadratic terms, both significant at 0.001 , for FE and RE specifications. The Hausman test again points to FE model in both cases. These supplementary results are important; both because they support the functional form of rent seeking we adopted in our model above, and because they are consistent with the approach taken by most of the existing literature on rent seeking, which assumes diminishing returns (see: Mueller, 2003).

Finally, we explore the sensitivity of our results to the definition of firm performance. Comparable to the set of models presented in Table 3, we experiment with measuring firm business performance by return on sales (defined by operating profit over sales), growth in 
profitability (defined by the growth rate of the operating profit) and growth in sales revenue. Our main results are insensitive to these alterations. All these additional results are available on request.

\section{Discussion}

We model the impact of uneven, non-transparent distribution of government controlled resources in China, and contrast entrepreneurs with managers of large, old, and state firms. By extending Puffer et al. (2010), we distinguish intrusive, non-transparent government from predatory government, and draw wider implications on the effects of institutional weaknesses in emerging markets. The existing modelling in the context of emerging economies focuses more on the predatory government such as that of Russia (e.g. Aidis et al., 2008). Our study fills the gap in the literature by concentrating on the intrusive non-transparent yet nonpredatory government in China.

We consider the lack of consistency in subsidies' distribution as an indicator of weak institutions, and demonstrate that the effects on young and small companies in comparison with more mature ones differ. We find that this type of weak institution leaves space for entrepreneurship, yet increases its cost by diverting managerial resources from productive engagements to rent-seeking activities. At the same time, our evidence suggests that young and small companies are much less affected compared to their larger and private counterparts, presumably because the fixed costs of building government connections and lobbying for government supports are relatively high, and they may initially mainly rely on private networks and a private set of resources. It follows, that for some new emerging companies, staying small may be a safe strategy, yet this is not a beneficial outcome from the wider economic point of view. 
We believe that our findings make a particular contribution to the economics of entrepreneurship research. Our arguments, simple formalisation, and empirical results, all suggest that new companies are less affected by lower institutional quality. This aspect of Chinese environment is consistent with what we observe around the world, for example in many Latin American countries as also noticed by Huang (2008). Weak institutions do not necessary result in low rates of entry. However, an important question that goes beyond entry is that of the subsequent dynamism, growth and innovation of young firms. Our findings do not shed direct light on that. But given that larger, private companies seem to be more affected by dysfunctional formal environments, weak institutional quality may either slow down business dynamism or, although dynamism perseveres, it comes at a higher cost.

At the same time, a non-transparent government is not the same as the big government we observe in developed countries. While these two aspects of government may be correlated as argued by Hayek (1960), they remain different (Aidis et al., 2012). Extensive government intervention that is not arbitrary may come with welfare cost via taxation and diversion of resources, but there is less social waste related to rent seeking. In particular, where all similar firms receive the same amount of subsidies, their performance is not affected negatively.

China, with its institutional and policy heterogeneity across space and across industrial sectors offers a very good empirical counterpart to test the simple model we developed. This institutional heterogeneity played an important part in China's reforms and economic success over the last decades, as it allowed experimentation and gradual institutional change without challenging the position of the political elites at the national level (Xu, 2011; Coase and Wang, 2012; Zhang, 2015). It is unique in that the emerging entrepreneurial sector has made significant institutional innovations based on norms and networks (Nee and Opper, 2012), and contributed to the fast pace of economic growth in the last three decades (Huang, 2008). However, as economists have come to agree, both the rate of growth and the pattern of 
growth matter. Creating inclusive formal institutions to support emergent private organisations is the key to sustaining economic development or to decreasing the cost of it in forgone consumption. Our findings in this paper demonstrate some areas of China's institutional weaknesses that generate an unlevelled playing ground for firms. Clearly, it is to the benefit of state sector firms and at the overall expense of firms' profitability, private firms in particular. This indicates the scope for further reforms. The institutional evolution in China, even if it does not follow a linear pattern (Huang, 2008; Zhang, 2015), offers hope that these reforms will come. While it is probably less likely that China will develop into a predatory state (or "oligarchic capitalism", to use Baumol et al. (2007) terminology), it remains to be seen if its development path will lead towards a form of "entrepreneurial capitalism" or towards the "state-led capitalism" model (ibid., p.60).

Last but not least, we need to stress an important limitation to our study. While we focus on entrepreneurs and managers, another field of research would be to understand both the broader question of motivation and the narrower question of rent-seeking behaviour within the Chinese state administration. While some researchers have already moved in that direction (e.g. Pei, 2006), more needs to be done. Entrepreneurship theory may contribute to our understanding of that field also, since Baumol's (1996) concept of 'unproductive entrepreneurship' can be applied to some forms of behaviour of government officials.

\section{Conclusion}

Baumol (1996) emphasises the impact of the 'rules of the game' on entrepreneurship, and de-emphasises long-term cultural factors: it is an optimistic perspective, as it suggests scope for reform. We take the lack of transparency in subsidies' distribution as a convenient indicator of a wider range of deficiencies in the institutional framework, not as the single most important institutional issue. However, we hope that our results identify subsidisation 
policies as needing reform. This is important for enhancing the institutional quality of China, so that the trajectory of growth may continue to transform China into an "entrepreneurial economy" (Baumol et al., 2007). 


\section{References}

Acemoglu, D. and J.A. Robinson. 2012. Why Nations Fail. London: Profile Books.

Aidis, R., Estrin, S., and Mickiewicz, T. (2008). Institutions and entrepreneurship development in Russia: A comparative perspective. Journal of Business Venturing, 23(6), 656-672.

Aidis, R., Estrin, S. and Mickiewicz, T. (2012). Size matters: Entrepreneurial entry and government. Small Business Economics, 39, 119-139.

Allen, F., Qian, J. and Qian, M. (2005). Law, finance, and economic growth in China. Journal of Financial Economics, 77, 57-116.

Baumol, W.J. (1996). Entrepreneurship: Productive, unproductive, and destructive. Journal of Business Venturing, 11, 3-22.

Baumol, W.J., Litan, R.E., Schramm (2007). Good Capitalism, Bad Capitalism, and the Economics of Growth and Prosperity. New Haven, CT: Yale University Press.

Brandt, L., Tombe, T., and Zhu, X. (2013). Factor market distortions across time, space and sectors in China. Review of Economic Dynamics, 16(1), 39-58.

Bruton, G. D., and Ahlstrom, D. (2003). An institutional view of China's venture capital industry: Explaining the differences between China and the West. Journal of Business Venturing, 18(2), 233-259.

Bruton, G. D., Ahlstrom, D., and Obloj, K. (2008). Entrepreneurship in emerging economies: Where are we today and where should the research go in the future. Entrepreneurship Theory and Practice, 32(1), 1-14.

Cai, H., Fang, H. and Xu, L.C. (2011). Eat, drink, firms, government: An investigation of corruption from the entertainment and travel costs of Chinese firms. Journal of Law and Economics, 54(1), 55-78.

Chen, Z., Sun, Y., Newman, A., and Xu, W. (2011). Entrepreneurs, organizational members, political participation and preferential treatment: Evidence from China. International Small Business Journal 30: 873-889.

Coase, R. and N. Wang. 2012. How China Became Capitalist. Houndmills: Palgrave Macmillan.

Correia, S. (2014). Explanation of the HDFE iteration with 3 FEs. Duke University, mimeo.

Driffield, N., Mickiewicz, T. and Temouri, Y. 2013. Institutional reforms, productivity and profitability: From rents to competition? Journal of Comparative Economics 41: 583-600.

Du, J., and Girma, S. (2007). Finance and firm export in China. Kyklos, 60(1), 37-54.

Du, J., and Girma, S. (2010). Red capitalists: Political connections and firm performance in 
China. Kyklos, 63(4), 530-545.

Du, J., A. Guariglia, and A. Newman. 2013. Do social capital building strategies influence the financing behavior of Chinese private small and medium-sized enterprises? Entrepreneurship Theory and Practice, DOI: 10.1111/etap.12051.

Du, J., X. Liu and Y. Zhou (2014). State Advances and Private Retreats? -Evidence From the Decomposition of the Chinese Manufacturing Aggregate Productivity. China Economic Review, 31, 459-474.

Estrin, S., Korosteleva, J., and Mickiewicz, T. (2013). Which institutions encourage entrepreneurial growth aspirations?. Journal of Business Venturing, 28(4), 564-580.

Frydman, R., Gray, C., Hessel, M. and Rapaczynski, A. 1999. When does privatization work? The impact of private ownership on corporate performance in the transition economies. Quarterly Journal of Economics 114: 1153-1191.

Girma, S., Gong, Y., and Görg, H. (2009). What determines innovation activity in Chinese state-owned enterprises? The role of foreign direct investment. World Development, 37(4), 866-873.

Haley, U. and Haley, G.. 2013. Subsidies to Chinese Industry. Oxford, UK: Oxford University Press.

Hayek, F. 1960. The Constitution of Liberty. Abington, UK: Routledge.

Hellman, J., Jones, G. and Kaufmann, D., 2003. Seize the state, seize the day: state capture and influence in transition economies. Journal of Comparative Economics 31: 751-773.

Huang, Y. (2003). Selling China: Foreign Direct Investment During the Reform Era. Cambridge: Cambridge University Press.

Huang, Y. (2008). Capitalism with Chinese characteristics: Entrepreneurship and the state. Cambridge: Cambridge University Press.

Kornai, J. 1986. Contradictions and Dilemmas. Studies on the Socialist Economy and Society. Cambridge, MA: MIT Press.

La Porta, R. and Lópes-de-Silanes, F. 1999. The benefits of privatization: Evidence from Mexico. Quarterly Journal of Economics 114: 1193-1242.

Lu, J. and Tao, Z. 2010. Determinants of entrepreneurial activities in China. Journal of Business Venturing 25: 261-273.

Mickiewicz, T. 2009. Hierarchy of governance institutions and the pecking order of privatisation. Post Communist Economies 21: 399-423.

Mueller, D.C. 2003. Public Choice III. Cambridge: Cambridge University Press.

Murphy, K.M., Shleifer, A. and Vishny, R. 1993. Why is rent-seeking so costly to growth? 
American Economic Review, Papers and Proceedings 83: 409-414.

Nee, V. and Opper, S. 2012. Capitalism from Below. Cambridge, MA: Harvard University Press.

Olson, M. 1982. The Rise and Decline of Nations. New Haven, CT: Yale University Press.

Parker, S. 2009. The Economics of Entrepreneurship. Cambridge: Cambridge University Press.

Pei, M. 2006. China's Trapped Transition. Cambridge MA: Harvard University Press.

Pigou, A. C. (2001 [1924]). The Economics of Welfare. New Brunswick, NJ: Transaction Publishers.

Posner, R. 1975. The social cost of monopoly and regulation. Journal of Political Economy 83: 807-827.

Puffer, S. M., McCarthy, D. J., and Boisot, M. (2010). Entrepreneurship in Russia and China: The impact of formal institutional voids. Entrepreneurship Theory and Practice, 34(3), 441467.

Rousseeuw, P.J., and C. Croux. 1993. Alternatives to the median absolute deviation. Journal of the American Statistical Association 88: 1273-1283.

Shleifer, A. and Vishny, R. 1994. Politicians and firms. Quarterly Journal of Economics 105: 995-1025.

Stigler, G.J. 1964, A theory of oligopoly, Journal of Political Economy 72: 44-61.

Tan, J., and Peng, M. W. (2003). Organizational slack and firm performance during economic transitions: Two studies from an emerging economy. Strategic Management Journal 24(13): 1249-1263.

Tang, J. and Tang J. 2012. Stakeholder-firm power difference, stakeholders' CSR orientation, and SMEs' environmental performance in China. Journal of Business Venturing 27: 436-455. Tsang, E.W. 1994. Threats and opportunities faced by private businesses in China. Journal of Business Venturing 9(6): 451-468.

Weingast, B. R. 1995. Economic Role of Political Institutions: Market-Preserving Federalism and Economic Development. Journal of Law, Economics and Organization 11(1): 1-31.

Wooldrige, J. 2002. Econometric Analysis of Cross Section and Panel Data. Cambridge MA: MIT Press.

Xin, K. K., and Pearce, J. L. (1996). Guanxi: Connections as substitutes for formal institutional support. Academy of Management Journal, 39(6): 1641-1658.

$\mathrm{Xu}, \mathrm{C}$. (2011) The fundamental institutions of China's reforms and development. Journal of Economic Literature 49(4): 1076-1151.

Zhang, Y. 2014. The contingent value of social resources: Entrepreneurs' use of debt-financing 
sources in Western China. Journal of Business Venturing, http://dx.doi.org/10.1016/j.jbusvent.2014.02.003.

Zhang, W. (2015). The Logic of the Market: An Insider's View of Chinese Economic Reform. Washington D.C: Cato Institute.

Zhao, L. and Aram, J.D. 1995. Networking and growth of young technology-intensive ventures in China. Journal of Business Venturing 10(5): 349-370.

Zhou, W. (2013). Political connections and entrepreneurial investment: Evidence from China's transition economy. Journal of Business Venturing, 28(2), 299-315. 


\section{Table 1: Summary statistics}

\begin{tabular}{|c|c|c|c|c|c|}
\hline Variables & Description & Mean & S.D. & Min & Max \\
\hline Profitability & Total profit over total assets & 0.087 & 0.193 & -0.233 & 1.096 \\
\hline Age & $\begin{array}{l}\text { Number of years since the } \\
\text { establishment of the firm }\end{array}$ & 11 & 11 & 1 & 97 \\
\hline Size & $\log ($ total revenue +1$)$ & 4.699 & 1.131 & 0.000 & 7.810 \\
\hline$H H I$ & Herfindahl-Hirschman index & 0.060 & 0.105 & 0.000 & 1.000 \\
\hline \multicolumn{6}{|c|}{ Dispersion indicators of subsidy } \\
\hline Subsidy coverage (coverage) & $\begin{array}{l}\text { Coverage ratio of subsidy in terms } \\
\text { of firm assets, by county/sic } 2 / \text { year }\end{array}$ & 0.222 & 0.282 & 0.000 & 1.000 \\
\hline $\begin{array}{l}\text { Median deviation of subsidy } \\
\text { (mdev) }\end{array}$ & $\begin{array}{l}\text { Median absolute deviation of } \\
\text { subsidy, scaled down by } 100 \text {. }\end{array}$ & 1.233 & 2.234 & 0.000 & 16.162 \\
\hline \multicolumn{6}{|c|}{ Firm ownership by official registration } \\
\hline State-owned firm & & 0.096 & 0.294 & 0.000 & 1.000 \\
\hline Collectively owned firm & & 0.147 & 0.355 & 0.000 & 1.000 \\
\hline Share-holding firm & & 0.152 & 0.359 & 0.000 & 1.000 \\
\hline Private firm & & 0.399 & 0.490 & 0.000 & 1.000 \\
\hline Foreign-invested firm & & 0.206 & 0.404 & 0.000 & 1.000 \\
\hline Observations & $2,399,047$ & & & & \\
\hline
\end{tabular}

Table 2: Correlation matrix

\begin{tabular}{l|ccccc} 
& Profitability & $\begin{array}{l}\text { Subsidy } \\
\text { coverage }\end{array}$ & Median deviation & Age & Size \\
\hline $\begin{array}{l}\text { Subsidy } \\
\text { coverage } \\
\begin{array}{l}\text { Median } \\
\text { deviation }\end{array}\end{array}$ & $-0.049 *$ & & & & \\
Age & $-0.059 *$ & $0.598 *$ & & & \\
Size & $-0.134 *$ & $-0.005 *$ & $0.032 *$ & $0.213 *$ & \\
HHI & $-0.078 *$ & $-0.007 *$ & $0.045 *$ & $0.017 *$
\end{tabular}

Note: Partial correlations. See Table 1 for definitions of variables. * indicates significance at the $5 \%$ level. 
Table 3: Determinants of firm's profitability

\begin{tabular}{|c|c|c|c|c|c|}
\hline & (1) & $(2)$ & (3) & (4) & $(5)$ \\
\hline \multirow[t]{2}{*}{ Collective firms } & $0.005 * *$ & $0.005^{* *}$ & 0.002 & $0.005 * *$ & $0.005 * *$ \\
\hline & $(0.002)$ & $(0.002)$ & $(0.002)$ & $(0.002)$ & $(0.002)$ \\
\hline \multirow[t]{2}{*}{ Shareholding firms } & $0.010 * * *$ & $0.010 * * *$ & $0.011 * * *$ & $0.010 * * *$ & $0.010 * * *$ \\
\hline & $(0.001)$ & $(0.001)$ & $(0.001)$ & $(0.001)$ & $(0.001)$ \\
\hline \multirow[t]{2}{*}{ Private firms } & $0.018 * * *$ & $0.018 * * *$ & $0.020 * * *$ & $0.018 * * *$ & $0.018 * * *$ \\
\hline & $(0.002)$ & $(0.002)$ & $(0.002)$ & $(0.002)$ & $(0.002)$ \\
\hline \multirow[t]{2}{*}{ Foreign firms } & $0.005 * *$ & $0.005 * *$ & $0.005^{*}$ & $0.005^{* *}$ & $0.005 * *$ \\
\hline & $(0.002)$ & $(0.002)$ & $(0.002)$ & $(0.002)$ & $(0.002)$ \\
\hline \multirow[t]{2}{*}{ Subsidies coverage } & 0.0002 & $-0.026^{*}$ & $-0.009 *$ & 0.011 & 0.005 \\
\hline & $(0.005)$ & $(0.011)$ & $(0.004)$ & $(0.020)$ & $(0.012)$ \\
\hline \multirow[t]{2}{*}{ Collective x Coverage } & & & $0.026 * *$ & & \\
\hline & & & $(0.010)$ & & \\
\hline Shareholding $\mathrm{x}$ & & & -0.007 & & \\
\hline Coverage & & & $(0.011)$ & & \\
\hline \multirow[t]{2}{*}{ Private $\mathrm{x}$ Coverage } & & & $-0.053 * * *$ & & \\
\hline & & & $(0.015)$ & & \\
\hline \multirow[t]{2}{*}{ Foreign Coverage } & & & 0.010 & & \\
\hline & & & $(0.013)$ & & \\
\hline \multirow[t]{2}{*}{ Coverage $\mathrm{x}$ Coverage } & & $0.030+$ & 0.004 & 0.015 & 0.006 \\
\hline & & $(0.017)$ & $(0.004)$ & $(0.029)$ & $(0.019)$ \\
\hline Collective $\mathrm{x}$ Coverage $\mathrm{x}$ & & & -0.019 & & \\
\hline Coverage & & & $(0.012)$ & & \\
\hline Shareholding $\mathrm{x}$ & & & 0.009 & & \\
\hline Coverage x Coverage & & & $(0.015)$ & & \\
\hline Private $\mathrm{x}$ Coverage $\mathrm{x}$ & & & $0.072 * *$ & & \\
\hline Coverage & & & $(0.023)$ & & \\
\hline Foreign $\mathrm{x}$ Coverage $\mathrm{x}$ & & & -0.016 & & \\
\hline Coverage & & & $(0.022)$ & & \\
\hline \multirow[t]{2}{*}{ Age of firm } & $-0.008 * * *$ & $-0.008 * * *$ & $-0.007 * * *$ & $-0.007 * * *$ & $-0.007 * * *$ \\
\hline & $(0.001)$ & $(0.001)$ & $(0.001)$ & $(0.001)$ & $(0.001)$ \\
\hline \multirow[t]{2}{*}{ Log of employment } & $0.020 * * *$ & $0.020 * * *$ & $0.020 * * *$ & $0.021 * * *$ & $0.020 * * *$ \\
\hline & $(0.001)$ & $(0.001)$ & $(0.001)$ & $(0.001)$ & $(0.001)$ \\
\hline \multirow[t]{2}{*}{ Market concentration } & $-0.019 * * *$ & $-0.021 * * *$ & $-0.020 * * *$ & $-0.021 * * *$ & $-0.020 * * *$ \\
\hline & $(0.004)$ & $(0.004)$ & $(0.004)$ & $(0.004)$ & $(0.004)$ \\
\hline Log of employment $x$ & & & & $-0.008 *$ & \\
\hline Coverage & & & & $(0.003)$ & \\
\hline Log of employment $x$ & & & & 0.003 & \\
\hline Coverage $\mathrm{x}$ Coverage & & & & $(0.004)$ & \\
\hline \multirow[t]{2}{*}{ Age $x$ Coverage } & & & & & $-0.003 * * *$ \\
\hline & & & & & $(0.000)$ \\
\hline Age $x$ Coverage $x$ & & & & & $0.002 * * *$ \\
\hline Coverage & & & & & $(0.000)$ \\
\hline Year 1999 & $0.006^{* *}$ & $0.006 * *$ & $0.006 * *$ & $0.006 * *$ & $0.006 * *$ \\
\hline \multirow[t]{2}{*}{ Year 2000} & $(0.002)$ & $(0.002)$ & $(0.002)$ & $(0.002)$ & $(0.002)$ \\
\hline & $0.016 * * *$ & $0.016 * * *$ & $0.015 * * *$ & $0.016 * * *$ & $0.015 * * *$ \\
\hline \multirow[t]{2}{*}{ Year 2001} & $(0.003)$ & $(0.003)$ & $(0.003)$ & $(0.003)$ & $(0.003)$ \\
\hline & $0.020 * * *$ & $0.020 * * *$ & $0.019 * * *$ & $0.020 * * *$ & $0.019 * * *$ \\
\hline \multirow[t]{2}{*}{ Year 2002} & $(0.004)$ & $(0.004)$ & $(0.004)$ & $(0.004)$ & $(0.004)$ \\
\hline & $0.028 * * *$ & $0.028 * * *$ & $0.027 * * *$ & $0.028 * * *$ & $0.026 * * *$ \\
\hline \multirow[t]{2}{*}{ Year 2003} & $(0.005)$ & $(0.005)$ & $(0.005)$ & $(0.005)$ & $(0.005)$ \\
\hline & $0.035 * * *$ & $0.035 * * *$ & $0.034 * * *$ & $0.035 * * *$ & $0.033 * * *$ \\
\hline
\end{tabular}




\begin{tabular}{llllll} 
Year 2004 & $(0.006)$ & $(0.006)$ & $(0.005)$ & $(0.006)$ & $(0.005)$ \\
Year 2005 & $0.040^{* * *}$ & $0.040^{* * *}$ & $0.040^{* * *}$ & $0.040^{* * *}$ & $0.038^{* * *}$ \\
& $(0.006)$ & $(0.006)$ & $(0.006)$ & $(0.006)$ & $(0.006)$ \\
Year 2006 & $0.065^{* * *}$ & $0.066^{* * *}$ & $0.065^{* * *}$ & $0.066^{* * *}$ & $0.063^{* * *}$ \\
& $(0.007)$ & $(0.007)$ & $(0.007)$ & $(0.007)$ & $(0.007)$ \\
Year 2007 & $0.080^{* * *}$ & $0.080^{* * *}$ & $0.079 * * *$ & $0.080^{* * *}$ & $0.078^{* * *}$ \\
& $(0.008)$ & $(0.008)$ & $(0.008)$ & $(0.008)$ & $(0.008)$ \\
Year 2008 & $0.111^{* * *}$ & $0.111^{* * *}$ & $0.110^{* * *}$ & $0.111^{* * *}$ & $0.108^{* * *}$ \\
& $(0.009)$ & $(0.009)$ & $(0.009)$ & $(0.009)$ & $(0.009)$ \\
R-squared & $0.139 * * *$ & $0.138 * * *$ & $0.137 * * *$ & $0.138 * * *$ & $0.135^{* * *}$ \\
Observations & 0.637 & 0.637 & 0.637 & 0.637 & 0.637 \\
Hausman test (p-value) & $2,205,070$ & $2,205,070$ & $2,205,070$ & $2,205,070$ & $2,205,070$ \\
\hline Number of id & 0.000 & 0.000 & 0.000 & 0.000 & 0.000 \\
\hline
\end{tabular}

Notes: The results reported in this table were estimated using fixed effects panel estimator, using reghdfe routine for Stata; see Correia (2014). Year dummies were included in all specifications. The ownership dummies interacted with the coverage of subsidy measure are: Collectively owned firms (COEs), Share-holding firms (SHR), pure private firms (private), and foreign invested firms (FOR), the reference group is State-owned firms (SOEs). The figures reported in parentheses are robust standard errors clustered by regional-city per year. The joint significance tests $(F$-tests) conducted to test if the coefficients associated with the independent variables are jointly statistically significant in the regression model. Hausman test statistics are reported for the endogeneity of fixed effects. Panel fixed effects estimator is preferred over random effects estimator. The observations that contained values of the fixed effects repeated only once were dropped. See Table 1 for definitions of all variables. * indicates significance at the $10 \%$ level. $* *$ indicates significance at the $5 \%$ level. $* * *$ indicates significance at the $1 \%$ level. We are indebted to the anonymous referee for helpful suggestions on estimation technique. 
Table 4: Determinants of firm's profitability; Subsidies dispersion measured by Mdev

\begin{tabular}{|c|c|c|c|c|c|}
\hline & (6) & (7) & $(8)$ & $(9)$ & (10) \\
\hline \multirow[t]{2}{*}{ Collective firms } & $0.005^{* *}$ & $0.005 * *$ & 0.003 & $0.005 * *$ & $0.005^{* *}$ \\
\hline & $(0.002)$ & $(0.002)$ & $(0.002)$ & $(0.002)$ & $(0.002)$ \\
\hline \multirow[t]{2}{*}{ Shareholding firms } & $0.010 * * *$ & $0.010 * * *$ & $0.011 * * *$ & $0.011 * * *$ & $0.011 * * *$ \\
\hline & $(0.001)$ & $(0.001)$ & $(0.001)$ & $(0.001)$ & $(0.001)$ \\
\hline \multirow[t]{2}{*}{ Private firms } & $0.018 * * *$ & $0.018 * * *$ & $0.019 * * *$ & $0.018 * * *$ & $0.018 * * *$ \\
\hline & $(0.002)$ & $(0.002)$ & $(0.002)$ & $(0.002)$ & $(0.002)$ \\
\hline \multirow[t]{2}{*}{ Foreign firms } & $0.005 * *$ & $0.005 * *$ & $0.006^{* *}$ & $0.006 * *$ & $0.006 * *$ \\
\hline & $(0.002)$ & $(0.002)$ & $(0.002)$ & $(0.002)$ & $(0.002)$ \\
\hline \multirow[t]{2}{*}{ Subsidies: med abs dev } & $-0.001 * *$ & $-0.001+$ & $-0.001 * * *$ & $0.005 * *$ & 0.001 \\
\hline & $(0.000)$ & $(0.001)$ & $(0.000)$ & $(0.002)$ & $(0.001)$ \\
\hline \multirow[t]{2}{*}{ Collective x Mdev } & & & $0.003 * * *$ & & \\
\hline & & & $(0.001)$ & & \\
\hline \multirow[t]{2}{*}{ Shareholding x Mdev } & & & -0.001 & & \\
\hline & & & $(0.001)$ & & \\
\hline \multirow[t]{2}{*}{ Private $\mathrm{x}$ Mdev } & & & $-0.002+$ & & \\
\hline & & & $(0.001)$ & & \\
\hline \multirow[t]{2}{*}{ Foreign x Mdev } & & & 0.0003 & & \\
\hline & & & $(0.001)$ & & \\
\hline \multirow[t]{2}{*}{ Mdev x Mdev } & & 0.000 & $-0.0002 * * *$ & $-0.0004 * *$ & $-0.0001 *$ \\
\hline & & $(0.000)$ & $(0.000)$ & $(0.000)$ & $(0.000)$ \\
\hline \multicolumn{2}{|l|}{ Collective x Mdev x } & & 0.000 & & \\
\hline \multicolumn{2}{|l|}{ Mdev } & & $(0.000)$ & & \\
\hline \multicolumn{2}{|l|}{ Shareholding $\mathrm{x}$ Mdev $\mathrm{x}$} & & $0.000 * * *$ & & \\
\hline \multicolumn{2}{|l|}{ Mdev } & & $(0.000)$ & & \\
\hline \multirow[t]{2}{*}{ Private x Mdev x Mdev } & & & $0.000 * * *$ & & \\
\hline & & & $(0.000)$ & & \\
\hline \multirow[t]{2}{*}{ Foreign x Mdev x Mdev } & & & $0.000 * * *$ & & \\
\hline & & & $(0.000)$ & & \\
\hline \multicolumn{2}{|l|}{ Log of employment $x$} & & & $-0.001 * * *$ & \\
\hline \multicolumn{2}{|l|}{ Mdev } & & & $(0.0002)$ & \\
\hline \multicolumn{2}{|l|}{ Log of employment $x$} & & & $0.0001 * * *$ & \\
\hline \multicolumn{2}{|l|}{ Mdev x Mdev } & & & $(0.0000)$ & \\
\hline Age x Mdev & & & & & $-0.0002 * * *$ \\
\hline & & & & & $(0.0000)$ \\
\hline Age x Mdev x Mdev & & & & & $0.0000 * * *$ \\
\hline & & & & & $(0.0000)$ \\
\hline Age of firm & $-0.008 * * *$ & $-0.008 * * *$ & $-0.007 * * *$ & $-0.007 * * *$ & $-0.007 * * *$ \\
\hline & $(0.001)$ & $(0.001)$ & $(0.001)$ & $(0.001)$ & $(0.001)$ \\
\hline Log of employment & $0.020 * * *$ & $0.020 * * *$ & $0.020 * * *$ & $0.020 * * *$ & $0.019 * * *$ \\
\hline & $(0.001)$ & $(0.001)$ & $(0.001)$ & $(0.001)$ & $(0.001)$ \\
\hline Market concentration & $-0.020 * * *$ & $-0.020 * * *$ & $-0.020 * * *$ & $-0.020 * * *$ & $-0.020 * * *$ \\
\hline & $(0.004)$ & $(0.004)$ & $(0.004)$ & $(0.004)$ & $(0.004)$ \\
\hline Year 1999 & $0.006^{* *}$ & $0.006 * *$ & $0.006 * *$ & $0.006^{* *}$ & $0.006^{* *}$ \\
\hline & $(0.002)$ & $(0.002)$ & $(0.002)$ & $(0.002)$ & $(0.002)$ \\
\hline Year 2000 & $0.016 * * *$ & $0.016 * * *$ & $0.015 * * *$ & $0.016 * * *$ & $0.015 * * *$ \\
\hline & $(0.003)$ & $(0.003)$ & $(0.003)$ & $(0.003)$ & $(0.003)$ \\
\hline Year 2001 & $0.020 * * *$ & $0.020 * * *$ & $0.019 * * *$ & $0.020 * * *$ & $0.019 * * *$ \\
\hline & $(0.004)$ & $(0.004)$ & $(0.004)$ & $(0.004)$ & $(0.004)$ \\
\hline Year 2002 & $0.028 * * *$ & $0.028 * * *$ & $0.027 * * *$ & $0.028 * * *$ & $0.027 * * *$ \\
\hline & $(0.005)$ & $(0.005)$ & $(0.005)$ & $(0.005)$ & $(0.005)$ \\
\hline Year 2003 & $0.035 * * *$ & $0.035 * * *$ & $0.034 * * *$ & $0.035 * * *$ & $0.034 * * *$ \\
\hline
\end{tabular}




\begin{tabular}{|c|c|c|c|c|c|}
\hline & $(0.006)$ & $(0.006)$ & $(0.005)$ & $(0.006)$ & $(0.005)$ \\
\hline \multirow[t]{2}{*}{ Year 2004} & $0.040 * * *$ & $0.040 * * *$ & $0.039 * * *$ & $0.040^{* * *}$ & $0.039 * * *$ \\
\hline & $(0.006)$ & $(0.006)$ & $(0.006)$ & $(0.006)$ & $(0.006)$ \\
\hline \multirow[t]{2}{*}{ Year 2005} & $0.065^{* * *}$ & $0.065 * * *$ & $0.065 * * *$ & $0.065^{* * *}$ & $0.064 * * *$ \\
\hline & $(0.007)$ & $(0.007)$ & $(0.007)$ & (0.007) & $(0.007)$ \\
\hline \multirow[t]{2}{*}{ Year 2006} & $0.080 * * *$ & $0.080 * * *$ & $0.079 * * *$ & $0.080^{* * * *}$ & $0.078 * * *$ \\
\hline & $(0.008)$ & $(0.008)$ & $(0.008)$ & $(0.008)$ & $(0.008)$ \\
\hline \multirow[t]{2}{*}{ Year 2007} & $0.111 * * *$ & $0.111 * * *$ & $0.110^{* * *}$ & $0.111^{* * *}$ & $0.109 * * *$ \\
\hline & $(0.009)$ & $(0.009)$ & $(0.009)$ & (0.009) & $(0.009)$ \\
\hline \multirow[t]{2}{*}{ Year 2008} & $0.138^{* * *}$ & $0.138 * * *$ & $0.137 * * *$ & $0.138 * * *$ & $0.136^{* * *}$ \\
\hline & $(0.011)$ & $(0.011)$ & $(0.011)$ & $(0.011)$ & $(0.011)$ \\
\hline Observations & $2,197,458$ & $2,197,458$ & $2,197,458$ & $2,197,458$ & $2,197,458$ \\
\hline R-squared & 0.638 & 0.638 & 0.638 & 0.638 & 0.638 \\
\hline Hausman test (p-value) & 0.000 & 0.000 & 0.000 & 0.000 & 0.000 \\
\hline Number of id & 472,696 & 472,696 & 472,696 & 472,696 & 472,696 \\
\hline
\end{tabular}

Notes: Please see Table 3 above. 
Figure 1. Subsidies and financial performance: a conceptual framework

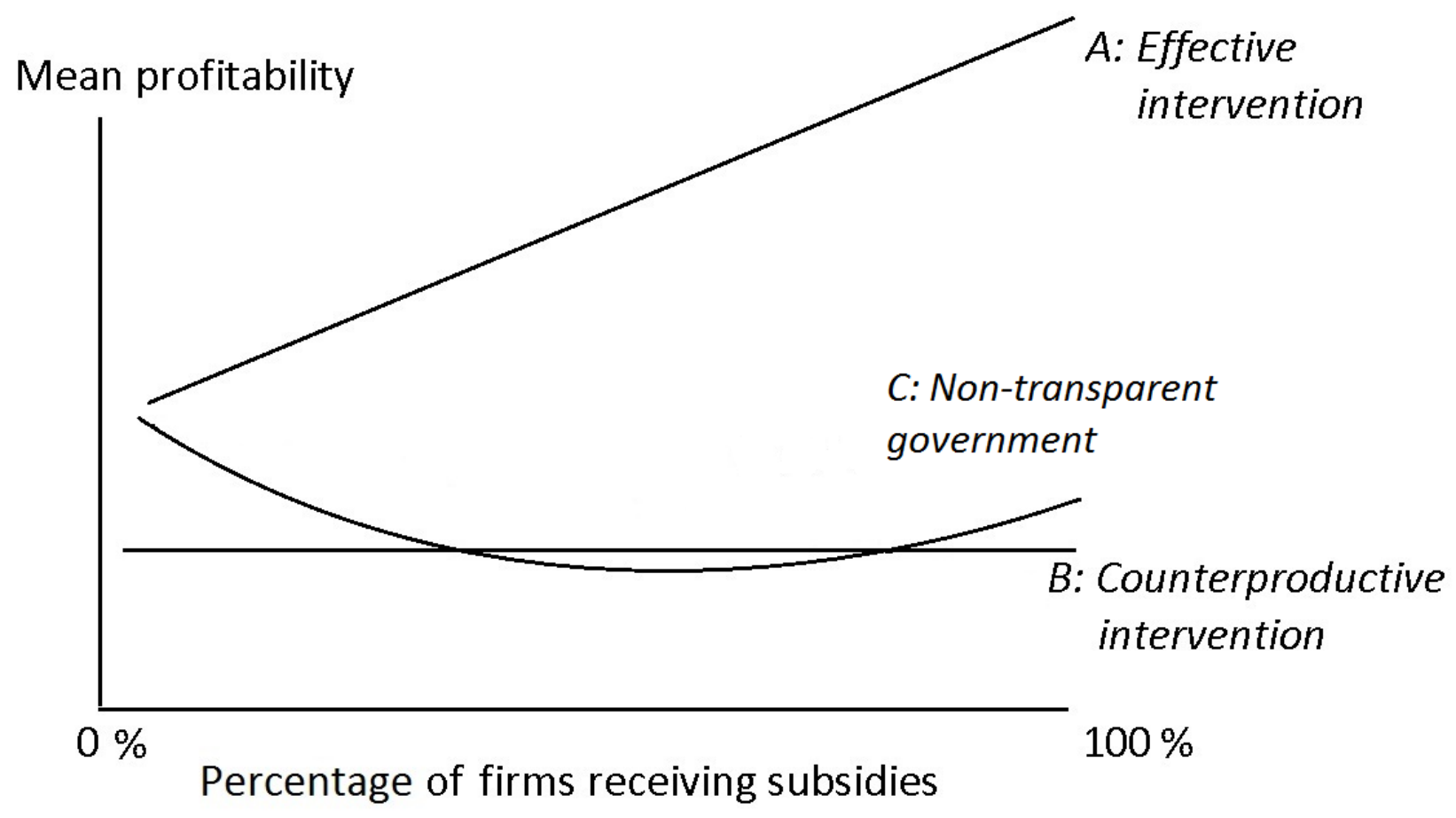


Figure 2. Weak institutions, ownership and profitability of Chinese firms

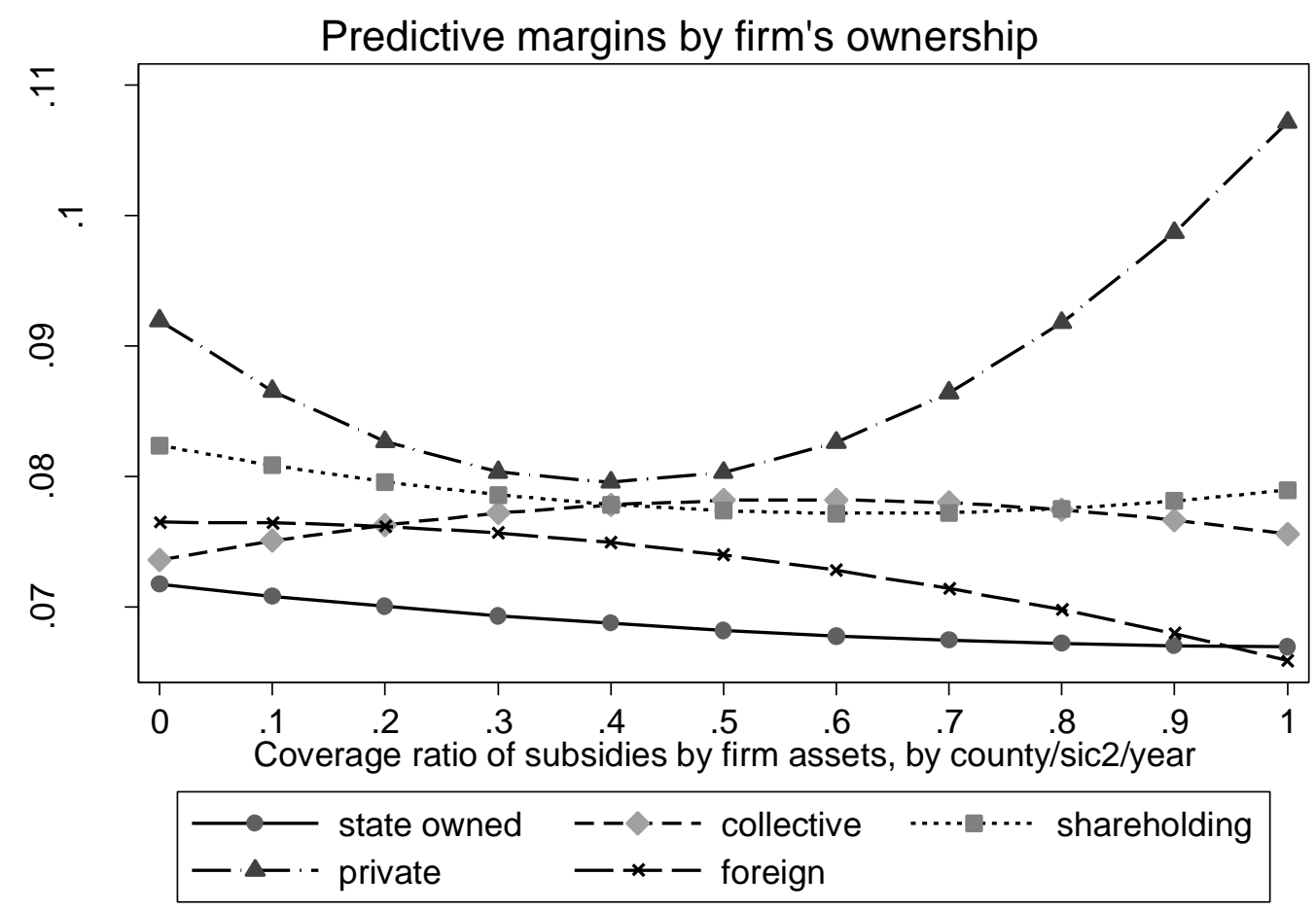


Figure 3. Weak institutions, size and profitability of Chinese firms.

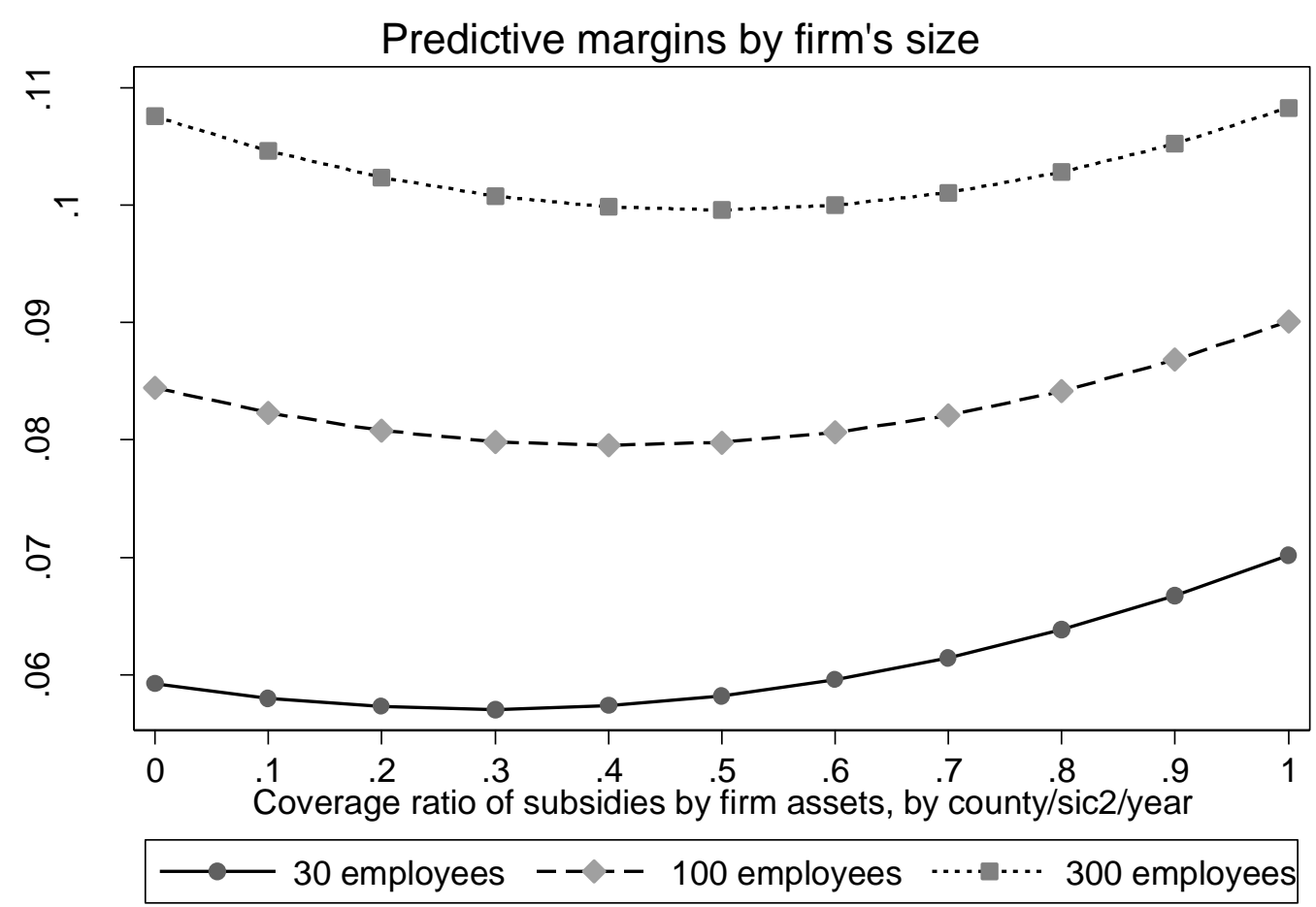


Figure 4. Weak institutions, age and profitability of Chinese firms.

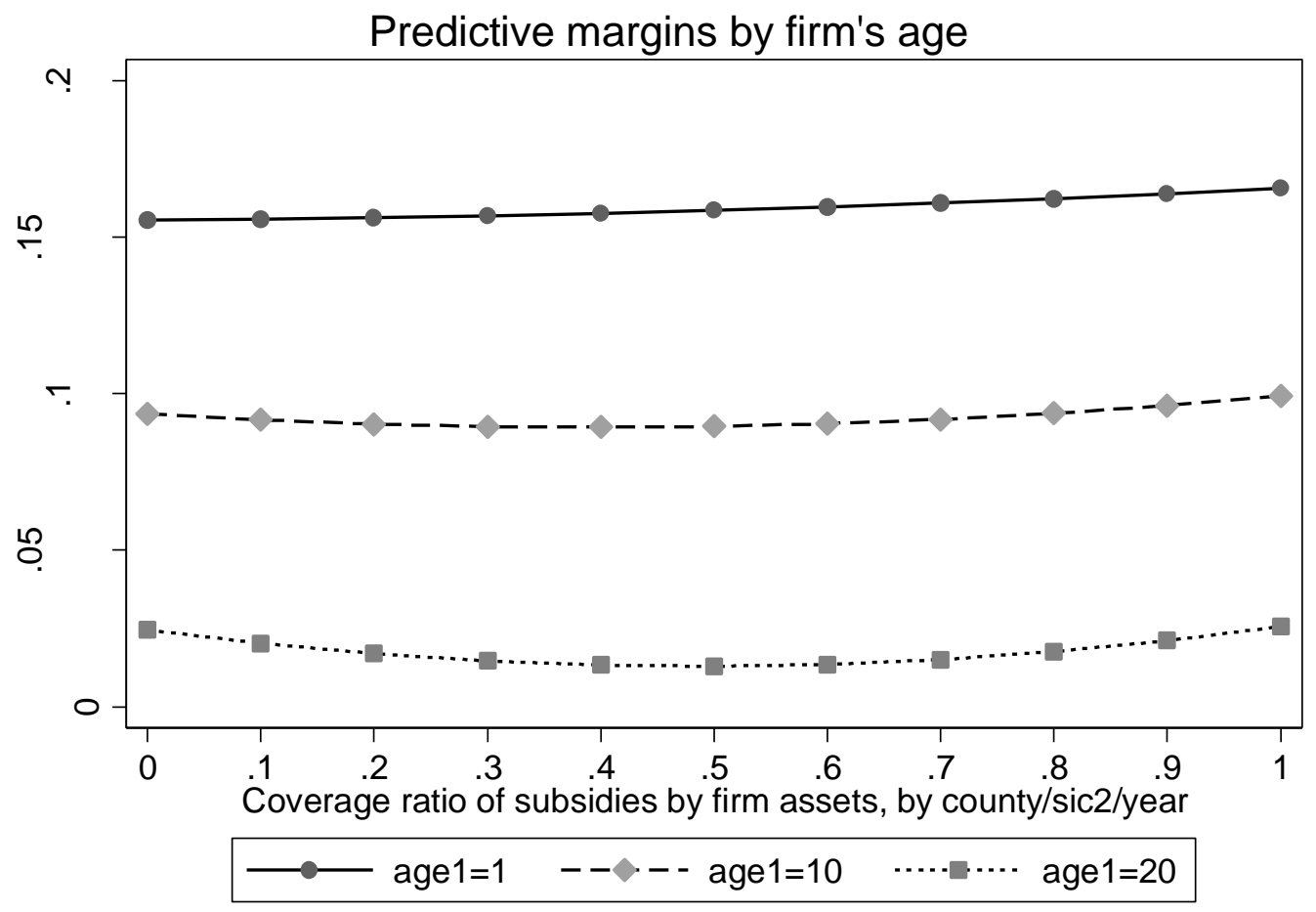

